\title{
PENGARUH UMPAN BALIK MENGGUNAKAN VIDEO TERHADAP MOTIVASI BELAJAR MAHASISWA PADA LATIHAN OSCE DI FAKULTAS KEDOKTERAN UNIVERSITAS MUHAMMADIYAH SUMATERA UTARA
}

\author{
M. Hafiz Muflih ${ }^{1}$, Ratih Yulistika Utami ${ }^{2}$ \\ ${ }^{1}$ Mahasiswa Fakultas Kedokteran Universitas Muhammadiyah Sumatera Utara \\ ${ }^{2}$ Unit Pendidikan Kedokteran FK UMSU \\ Jln. Gedung arca No.53, Medan - Sumatera Utara, 2019 \\ Telp: (061)7350163, Email: hafizmuflih1111@ gmail.com
}

\begin{abstract}
Introduction: Motivation is the power which drives someone to do something. Motivation can influence the result of student learning. Clinic skill will be marked using OSCE method (Objective Structured Clinical Examination). OSCE is a test with mark base on skils (performance) observed when doing some clinic skill which are tested objectively and structurally. The feed back using video has superiority compare with other feed back using oral or written. The using of video is ensured to be able to correct lecture becomes more interesting because students can listen the explanation from lecturer, via video, students can see clearly the lecturer way to correct their mistakes by watching the video again or by moving on or moving back the video. Method: This is quasi experimental research to mark the influence of using video feed back on student motivation learning on OSCE exercise at UMSU medical direction. Taking sample method in this research is total sampling. The samples are 98 students of Medical Direction of UMSU 2017 grade. Research Result: This research show that there is a significant difference among students motivated learning in intervention group and strong control of the students of medical direction of UMSU with mark p:0.001 $(<0.05)$. Conclusion: In this research can be concluded that feed back using video influences on students motivation or exercise OSCE in medical direction of UMSU.
\end{abstract}

Key word : motivation, feed back, OSCE, feed back using video 


\section{PENDAHULUAN}

Keterampilan klinik merupakan komponen penting dalam pendidikan dokter. Pembelajaran keterampilan klinik saat ini sudah mengalami pergeseran dan dimulai dari tahap preklinik pada setting khusus yang dikenal sebagai skills-lab. Kegiatan keterampilan klinik dasar pada setting skills-lab ini mempunyai kekurangan yaitu membutuhkan sumber daya manusia yang banyak dan biaya yang mahal. Ada beberapa faktor yang dapat mempengaruhi keberhasilan kegiatan keterampilan klinik dasar di skills-lab tersebut, di antara lain ialah konten materi, metode penyampaian, peserta, instruktur, peralatan serta lingkungan pembelajarannya. Kesemua faktor di atas harus sesuai sehingga proses kegiatan keterampilan klinik dasar dapat tercapai tujuannya. ${ }^{1}$

Umpan balik verbal diberikan secara individu adalah bentuk ideal untuk mahasiswa. ${ }^{2}$ Penelitian menunjukkan bahwa umpan balik menggunakan video dapat meningkatkan motivasi mahasiswa. Video itu sendiri merupakan media yang dapat meningkatkan motivasi belajar mahasiswa. ${ }^{3}$

Pada saat ini, beberapa penelitian menunjukkan bahwa umpan balik menggunakan video memiliki keunggulan dibandingkan dengan umpan balik secara lisan maupun tulisan. Video telah berhasil digunakan dalam pembelajaran dan pengajaran. ${ }^{4}$ Penggunaan video diyakini dapat membuat koreksi dosen pengajar menjadi lebih menarik karena di samping mendengarkan penjelasan dosen, melalui video mahasiswa dengan jelas mampu melihat cara dosen mengkoreksi kesalahan mereka dengan memutar video lagi atau memajukan dan memundurkan video. Ada beberapa keunggulan penggunaan feedback dalam bentuk video, yaitu: 1) pembelajaran menjadi lebih inklusif dengan penekanan pada gaya belajar ganda, yang lebih dikenal dengan gaya multimodal, dengan menggunakan informasi teknologi 2) lebih banyak feedback bisa diberikan dengan video daripada teks saja; 3) bahwa feedback multimodal lebih sesuai dengan mahasiswa yang setiap harinya diekspos dengan berbagai media audio dan video dibandingkan dengan 10 tahun yang lalu; 4) memungkinkan digunakan untuk pembelajaran jarak jauh dan feedback yang lebih personal; 5) suara pada video dikatakan memiliki manfaat yang penting yang tidak bisa diperoleh dalam feedback tekstual. ${ }^{5}$

Motivasi merupakan kekuatan yang mendorong seseorang untuk melakukan sesuatu. Motivasi dapat mempengaruhi hasil belajar mahasiswa. ${ }^{6}$

Berdasarkan masalah diatas maka peneliti tertarik untuk melakukan penilitian tentang Pengaruh Umpan Balik menggunakan Video terhadap Latihan OSCE di FK UMSU.

\section{METODE PENELITIAN}

Penelitian ini merupakan penelitian eksperimen semu dengan Rancangan Eksperimen Semu (Quasi Eksperimental Research) untuk menilai pengaruh umpan balik menggunakan video terhadap motivasi belajar mahasiswa pada saat Latihan OSCE di FK UMSU.

Penelitian ini dilakukan di Fakultas Kedokteran Universitas Muhammadiyah Sumatera Utara. Penelitian ini akan dilakukan pada bulan Juli-Desember 2018. Populasi penelitian ini adalah mahasiswa Fakultas Kedokteran UMSU angkatan 2017.

Teknik pengambilan sampel dalam penelitian ini adalah Total Sampling. Sampel yang diambil adalah Mahasiswa FK UMSU Angkatan 2017 dengan jumlah sampel 99 orang yang sesuai dengan kriteria inklusi dan kriteria drop out. 
Kriteria Inklusi :

1. Mahasiswa Aktif

2. Bersedia menjadi responden

Kriteria drop out:

1. Tidak hadir pada saat evaluasi LO

2. Tidak mengisi kuesioner

\section{HASIL PENELITIAN}

Penelitian ini dilakukan di Fakultas Kedokteran Universitas Muhammadiyah Sumatera Utara yang terletak di Jalan Gedung Arca No. 53 Kec. Medan Area, Kota Medan. Penelitian ini dilaksanakan pada bulan Juli sampai dengan Desember 2018 dengan jumlah sampel yang diteliti sebanyak 99 orang. Akan tetapi yang memenuhi kriteria inklusi sebanyak 86 orang dikarenakan mahasiswa tidak hadir dalam pengisian kuesioner.

Tabel 1 Gambaran Responden

\begin{tabular}{lccccc}
\hline \multirow{2}{*}{ Kelompok } & \multicolumn{3}{c}{ Jenis kelamin } & \\
\cline { 2 - 4 } & \multicolumn{2}{c}{ Laki-laki } & \multicolumn{2}{c}{ Perempuan } & Total \\
\cline { 2 - 4 } & $\mathrm{N}$ & $\%$ & $\mathrm{~N}$ & $\%$ & \\
\hline Intervensi & 15 & 17,4 & 28 & 32,5 & 43 \\
Kontrol & 11 & 12,8 & 32 & 37,3 & 43 \\
\hline Total & 26 & 30,2 & 60 & 69,8 & 86 \\
\hline
\end{tabular}

Berdasarkan Tabel 1 menunjukkan bahwa secara keseluruhan, responden perempuan lebih banyak dengan jumlah 60 orang $(69,8 \%)$ dan laki-laki 26 orang $(30,2 \%)$. Pada kelompok intervensi jumlah responden laki-laki adalah 15 orang $(17,4 \%)$ dan jumlah responden perempuan adalah 28 orang $(32,5 \%)$. Pada kelompok kontrol jumlah responden laki-laki 11 orang $(12,8 \%)$ dan jumlah responden perempuan adalah 32 orang $(37,3 \%)$.

Tabel 2 Distribusi frekuensi berdasarkan responden

motivasi

\begin{tabular}{lcc}
\hline \multicolumn{1}{c}{ Motivasi } & N & $\%$ \\
\hline Sedang & 3 & 3,5 \\
Baik & 46 & 53,4 \\
Sangat Baik & 37 & 43,1 \\
\hline Total & 86 & 100 \\
\hline
\end{tabular}

Berdasarkan Tabel 2 menunjukkan bahwa secara keseluruhan, gambaran responden motivasi terbanyak adalah baik sebanyak 46 orang $(53,4 \%)$, sedangkan responden motivasi sangat baik sebanyak 37 orang $(43,1 \%)$ dan responden motivasi sedang sebanyak 3 orang $(3,5 \%)$.

Tabel 3 Distribusi frekuensi motivasi berdasarkan jenis kelamin

\begin{tabular}{lccccc}
\hline \multirow{2}{*}{ Motivasi } & \multicolumn{5}{c}{ Jenis Kelamin } \\
& Laki-laki & $\%$ & Perempuan & $\%$ & p value \\
\hline Sedang & 0 & 0 & 3 & 3,5 & \\
Baik & 19 & 22,1 & 27 & 31,4 & 0,121 \\
Sangat Baik & 7 & 8,1 & 30 & 34,9 & \\
Total & 26 & 30,2 & 60 & 69,8 & \\
\hline
\end{tabular}

Berdasarkan

Tabel 3 menunjukkan bahwa adanya perbedaan gambaran motivasi antara responden laki-laki dan perempuan. Gambaran responden motivasi terbanyak pada perempuan terdapat pada responden motivasi sangat baik yaitu sebanyak 30 orang $(34,9 \%)$ sedangkan responden motivasi terbanyak pada laki-laki terdapat pada responden motivasi baik yaitu sebanyak 19 orang $(22,1 \%)$ dan responden motivasi terendah terdapat pada laki-laki dan perempuan yaitu pada responden motivasi sedang. Dan pada uji homogenitas menunjukkan bahwa perbedaan rerata motivasi berdasarkan jenis kelamin adalah 0,121 ( $>00,05)$ yang berarti data homogen.

Tabel 4 Distribusi frekuensi motivasi berdasarkan Indeks Prestasi

\begin{tabular}{lcccccccc}
\hline Motivasi & Memuaskan & $\%$ & $\begin{array}{c}\text { Indeks Prestasi } \\
\text { Sangat } \\
\text { Memuaskan }\end{array}$ & $\%$ & Cum & Laude & p value \\
\hline Sedang & 0 & 0 & 2 & 2,2 & 1 & 1,1 & \\
Baik & 8 & 9,3 & 34 & 39,4 & 4 & 4,5 & 0,204 \\
Sangat & 13 & 15,8 & 2 & 2,2 & 22 & 25,5 & \\
Baik & 21 & 25,1 & 38 & 43,8 & 27 & 31,1 & \\
Total & \multicolumn{7}{c}{ Tabel } & 4
\end{tabular}
menunjukkan bahwa motivasi sedang dengan indeks prestasi memuaskan sebanyak 0 orang $(0 \%)$, sangat memuaskan sebanyak 2 orang $(2,2 \%)$, cum laude sebanyak 1 orang $(1,1 \%)$. 
Motivasi baik dengan indeks prestasi memuaskan sebanyak 8 orang $(9,3 \%)$, sangat memuaskan sebanyak 34 orang $(39,4 \%)$, cum laude sebanyak 4 orang $(4,5 \%)$. Sedangkan motivasi sangat baik dengan indeks prestasi memuaskan sebanyak 13 orang $(15,8 \%)$, sangat memuaskan sebanyak 2 orang $(2,2 \%)$, cum laude sebanyak 22 orang $(25,5 \%)$. Dan pada uji homogenitas menunjukkan bahwa perbedaan rerata motivasi berdasarkan jenis kelamin adalah 0,204 ( $>0,05)$ yang berarti data homogen.

\section{Selanjutnya dilakukan uji normalitas yang bertujuan untuk mengetahui apakah distribusi data yang didapatkan melalui penyebaran kuesioner SMQ-II berdistribusi normal atau tidak. Uji normalitas yang digunakan adalah uji normalitas Kolmogorov-Smirnov.}

Hasil uji normalitas didapatkan nilai $p=0,023 \quad(<0.05)$, maka data motivasi tidak berdistribusi normal. Sehingga pengujian dilanjutkan dengan menggunakan Uji Mann Withney.

Tabel 5 Tabel Uji Mann Withney

\begin{tabular}{lcl}
\hline \multicolumn{1}{c}{ Kelompok } & $\begin{array}{c}\text { Median } \\
\text { (Minimum-Maximum) }\end{array}$ & \multicolumn{1}{c}{ Nilai P } \\
\hline Kelompok Intervensi (n=43) & $\begin{array}{l}4,55(3,80-5,00) \\
\text { Kelompok Kontrol (n=43) } \\
4,30(3,15-5,00)\end{array}$ & 0,000 \\
\hline \multicolumn{4}{c}{ Berdasarkan } & tabel & $\mathbf{5}$
\end{tabular}

menunjukkan hasil analisis dari hasil uji statistik Mann-Whitney didapatkan hasil $\mathrm{p}=0.000 \quad(\mathrm{p}<0.05) \quad$ maka dapat disimpulkan adanya perbedaan yang signifikan antara motivasi belajar mahasiswa pada kelompok intervensi dan kelompok kontrol mahasiswa pada saat latihan OSCE.

\section{PEMBAHASAN}

Berdasarkan hasil penelitian yang dilakukan hasil Mann Whitney menunjukkan bahwa terdapat adanya perbedaan yang signifikan antara motivasi belajar mahasiswa pada kelompok intervensi dan kelompok kontrol mahasiswa Fakultas Kedokteran Universitas Muhammadiyah Sumatera Utara angkatan 2017 setelah diberikan umpan balik menggunakan video pada saat Latihan OSCE, artinya umpan balik menggunakan video berpengaruh terhadap motivasi belajar mahasiswa Fakultas Kedokteran Universitas Muhammadiyah Sumatera Utara. Hal ini sesuai dengan penelitian yang dilakukan di Fakultas Pendidikan Guru Prof. Dr. Hamka di Jakarta tahun 2009 yang menyatakan bahwa hasil belajar micro teaching mahasiswa yang mendapat umpan balik rekaman video dan memiliki motivasi belajar tinggi lebih tinggi dari hasil belajar mahasiswa yang mendapat umpan balik dengan teman sejawat. $^{8}$

Hal ini juga berkaitan dengan beberapa faktor yang mempengaruhi motivasi, yaitu (1) Kebutuhan: proses adanya motivasi karena adanya kebutuhan atau rasa kekurangan sesuatu. Individu yang mempunyai kebutuhan akan termotivasi untuk menggerakkan tingkah lakunya untuk memuaskan kebutuhannya tersebut. (2) Sikap: sikap individu terhadap suatu objek akan melibatkan emosi (perasaan senang atau tidak senang), pengarahan atau penghindaran terhadap objek dan suatu sasaran kognitif yaitu bagaimana individu membayangkan atau mempersepsikan sesuatu. (3) Minat: minat akan memunculkan perhatian khusus terhadap suatu objek dan akan menimbulkan motivasi. (4) Nilai: merupakan suatu pandangan individu akan sesuatu hal atau suatu tujuan atau yang dianggap penting dalam hidupnya. (5) Aspirasi: merupakan harapan individu akan sesuatu, dan individu akan berusaha untuk mencapai hal-hal yang diharapkan. ${ }^{7}$

Untuk meningkatkan motivasi belajar mahasiswa itu sendiri karena adanya suatu kebutuhan sesuai dengan penelitian yang dilakukan di Fakultas Ilmu Tarbiyah dan Keguruan 
Universitas Islam Negeri Raden Fatah Palembang pada tahun 2017.Hasil penelitian tersebut menunjukkan bahwa kebutuhan dalam meningkatkan motivasi belajar adalah dengan menggunakan video. ${ }^{9}$ Salah satu cara untuk menghasilkan proses pembelajaran yang menarik adalah dengan memanfaatkan video sebagai sumber dan media pembelajaran. Berbagai hasil penelitian menunjukkan bahwa orang lebih tertarik belajar menggunakan media video daripada belajar melalui media teks dan gambar diam. ${ }^{10}$ Selain itu menurut penelitian yang dilakukan di Fakultas Ilmu Tarbiyah dan Keguruan Universitas Islam Negeri Sunan Kalijaga tahun 2016 menunjukkan bahwa peran media pembelajaran berbentuk media audio visual sebagai usaha meningkatkan minat belajar dan media video dapat menarik minat mahasiswa untuk belajar. $^{11}$

Menurut penelitian yang dilakukan di Program Studi Pendidikan Dokter (PSPD) Fakultas Kedokteran dan Ilmu Kesehatan Universitas Jambi pada tahun 2016 menyebutkan bahwa adanya efektivitas media rekaman terhadap keterampilan klinik neurologi pada proses KKD menyatakan bahwa ada perbedaan pada hasil keterampilan dari rata rata hasil belajar di kelompok yang memakai media video dan media konvensional. $^{12}$ Kelebihan metode menggunakan media audio visual (video) menurut penelitian yang dilakukan di Fakultas Keguruan dan Ilmu Pendidikan Universitas Maritim Raja Ali Haji Tanjung Pinang pada tahun 2014 menyebutkan bahwa dapat menyajikan objek secara lebih detail dan dapat diperlambat dan dipercepat sehingga pembelajaran yang dilakukan dapat diselaraskan dengan keinginan mahasiswa dan video merupakan media tepat untuk memperlihatkan contoh keterampilan yang menyangkut gerak. ${ }^{13}$ Sedangkan menurut penelitian yang dilakukan di Fakultas Keguruan dan Ilmu Pendidikan Universitas Sebelas Maret pada tahun 2016 juga menyebutkan bahwa kelebihan media audio visual dapat memperjelas penyajian pesan agar tidak bersifat verbalitas dan media audio visual ini juga dapat mengatasi keterbatasan ruang,waktu dan daya indra sehingga pembelajaran yang dilakukan dapat disesuaikan dengan kemampuan mahasiswa. Pembelajaran dengan media konvensional adalah pembelajaran yang sifatnya berpusat pada guru dan pengajar. ${ }^{14}$

Ada pun beberapa bentuk dan cara untuk menumbuhkan motivasi dalam kegiatan belajar antara lain: memberi angka (nilai), hadiah, saingan atau kompetensi, ego-involvement, mengetahui hasil, pujian, hukuman, hasrat untuk belajar, minat, tujuan yang diakui. ${ }^{15}$ Dan menurut Oemar juga sependapat dengan uraian diatas, untuk memotivasi belajar mahasiswa dapat dilakukan dengan cara pemberian penghargaan dan ganjaran, pemberian angka atau grade, keberhasilan atau tingkat aspirasi, pemberian pujian, kompetisi dan kooperasi serta pemberian harapan. ${ }^{16}$

Seseorang mahasiswa yang memiliki kecerdasan intelektual yang baik maka mampu memahami dan dapat membaca dengan penuh pemahaman serta menunjukkan keingintahuan. Yang berarti kecerdasan intelektual berpengaruh terhadap prestasi akademik mahasiswa. ${ }^{17}$ Kemudian didukung oleh penelitian yang dilakukan di Fakultas Ekonomi Universitas Muhammadiyah Surabaya tahun 2017 menunjukkan bahwa kecerdasan intelektual itu sendiri merupakan kemampuan seseorang memperoleh ilmu pengetahuan, dapat menguasai dalam menghadapi masalah yang di alami oleh mahasiswa. ${ }^{18}$ Hal ini juga sesuai dengan penelitian ini bahwa motivasi sangat baik dimiliki oleh 
mahasiswa yang memiliki Indeks Prestasi Sementara cum laude.

Umpan balik itu sendiri merupakan pembelajaran yang dapat meningkatkan motivasi, kemampuan dan hasil belajar mahasiswa baik dengan metode lisan, tertulis maupun menggunakan media video. Pemberian umpan balik menggunakan video dapat meningkatkan motivasi mahasiswa lebih baik dibandingkan dengan metode lisan dan tertulis. Hal tersebut disebabkan karena video dapat memperlihatkan keterampilan klinis yang dilakukan secara detail dan dapat diulang kembali.

Dalam penelitian ini terdapat keterbatasan penelitian seperti: tidak melihat motivasi mahasiswa pada saat sebelum dan sesudah latihan OSCE. Hal tersebut tidak dapat menggambarkan motivasi belajar mahasiswa spesifik untuk setiap kelompok, yaitu pada kelompok intervensi maupun kelompok kontrol.

\section{KESIMPULAN}

Pada penelitian ini dapat disimpulkan bahwa umpan balik menggunakan video berpengaruh terhadap motivasi belajar mahasiswa pada saat Latihan OSCE di FK UMSU. Hal tersebut menunjukkan bahwa rekaman video dapat menjadi sarana pembelajaran yang lebih efektif dalam proses Latihan OSCE dan memudahkan responden untuk mengingat setiap kegiatan keterampilan klinis dasar. Selain itu rekaman video juga dapat meningkatkan motivasi belajar mahasiswa dalam Latihan OSCE.

\section{SARAN}

Berdasarkan pengamatan penelitian ini, terdapat beberapa saran yang mungkin menjadi bahan pertimbangan untuk meningkatkan pembelajaran pada Latihan OSCE mahasiswa Fakultas Kedokteran Universitas Muhammadiyah Sumatera
Utara dan Fakultas Kedokteran lainnya di Indonesia.

1. Bagi mahasiswa Fakultas Kedokteran Universitas Muhammadiyah Sumatera Utara dapat menjalankan program Latihan OSCE dengan menggunakan metode rekaman video sebagai sarana untuk evaluasi mahasiswa sehingga mahasiswa lebih memahami dan mengingat ilmu yang telah dipelajari dalam kegiatan keterampilan klinis/skills lab

2. Dilakukan penelitian lanjutan tentang efektivitas media rekaman video terhadap proses belajar mengajar lainnya dan penelitian ini sebagai referensi untuk penelitian selanjutnya.

\section{REFERENSI}

1. Risma G. Kecemasan dalam Objective Structured Clinical Examination (OSCE). J Agromed Unila 2015; 2(4): 419424.

2. Brown, S. and Knight, P. Assessing Learners in HigherEducation, London: Kogan Page. 1994.

3. Paul S, Dawson KP, LanphearJH, CheemaMY. Video recording feedback: a feasible and effective approach to teaching history-taking and physical examination skills in undergraduate paediatric medicine. Medical Education. 1998;32:332-6.

4. Fernando NJS, Leader BL, Cole J V, Lecturer S, Co-ordinator L. Scanning the Horizons : Institutional Research in a Borderless World Higher Education Institutional Research Network Conference Kingston University Live Lecture Streaming for Distributed Learning Live Lecture 
Streaming for Distributed Learning. 2011:1-7. http://www.heir2011.org.uk/con ference-papers/papers/Fernando

5. Adnyani LDS, Agustini DAE. Persepsi Mahasiswa Terhadap Feedback Langsung Berbentuk Video. 2014:425-431.

6. Lisiswanti R, Sanusi R, Prihatiningsih TS. Hubungan Motivasi dan Hasil Belajar Mahasiswa Kedokteran. J Pendidik Kedokt Indones Indones $\mathrm{J}$ Med Educ. 2017;4(1):1-6. Available from: https://jurnal.ugm.ac.id/jpki/arti cle/view/25259

7. Ningrum, A.J. 2011. Faktorfaktor yang Mempengaruhi Motivasi Ibu Menyekolahkan Anak din Homeschooling Kak Seto Semarang. Skripsi. Tidak Diterbitkan. Semarang : Fakultas Psikologi Unika Soegijapranata.

8. Mochtar M.Noor. Pengaruh Pemberian Umpan Balik Rekaman Video Hasil Belajar Micro Teaching Mahasiswa; Jakarta. 19(April) 2009:43-54 .

9. Vuspa LS. Pengaruh Media Pembelajaran Video Terhadap Motivasi Belajar Fikih di MTS Patra Plaju : Palembang. 2017.

10. Fadhli, M. Pengembangan Media Pembelajaran Berbasis Video Kelas IV Sekolah Dasar. Jurnal Dimensi Pendidikan dan Pembelajaran, 3(1). 2015. 2429.

11. Hikmasari, Mifthurohmah. Peran Media Audio Visual Dalam Meningkatkan Minat Belajar PAI Siswa Kelas III : Yogyakarta. 2016.

12. Aryanty N, Puspasari A, Purwakhanti A. Perbandingan Efektifitas Pembelajaran Clinical Skill Lab (CSL) dengan Menggunakan Video Ajar
Keterampilan Klinik Neurologi terhadap Demonstrasi oleh Instruktur. Jambi Medical Journal;2(2). 2014.

13. Puspita Sari, S.D. Efektivitas Media Audiovisual terhadap kemampuan menyimak dongeng siswa VII SMP Negeri 7 Tanjung Pinang tahun ajaran 2013/2014: Indonesia JP. 2014.

14. Mayasari D. Penggunaan Media Audio Visual Video untuk Meningkatkan Hasil Belajar Siswa pada Mata Pelajaran Sosiologi Kelas X-2 SMANegeri Kebakkramat Tahun Ajaran 2015/2016. SOSIALITAS; Jurnal Ilmiah Pend. Sos Ant. 2016 May 24;7(2).

15. A.M, Sardiman. Interaksi dan Motivasi Belajar Mengajar. PT Raja Grafindo Persada. Jakarta. 2003 : 91-95)

16. Hamalik, Oemar. 2004. Proses Belajar Mengajar. Bumi Aksara. Jakarta : 2004. 184-186)

17. Azwar, S. Pengantar Psikologi Inteligensi. Cetakan Keempat. Yogyakarta : Pustaka Pelajar. 2004.

18. Nuraini F. Kecerdasan Emosional, Kecerdasan Intelektual Spiritual Terhadap Pemahaman Akuntansi Dasar Dengan Motivasi Sebagai Variabel Moderating. J Account Sci.;Vol.1 No2.:93-118. http://ojs.umsida.ac.id/index.php ljas. 
Universitas Muhammadiyah Sumatera Utara 